\title{
The population dynamic of honeydew moth [Cryptoblabes gnidiella Mill. (Lepidoptera: Pyralidae)] in vineyard in Antalya
}

\author{
Antalya ilinde bağda portakal güvesi [Cryptoblabes gnidiella Mill. (Lepidoptera: \\ Pyralidae)]'nin popülasyon değişimi
}

\author{
Mehmet KEÇECİi \\ Malatya Turgut Özal Üniversitesi, Ziraat Fakültesi, Bitki Koruma Bölümü, Malatya, Türkiye \\ Corresponding author (Sorumlu yazar): M. Keçeci, e-mail (e-posta): kececitr@yahoo.com
}

\section{ARTICLE INFO}

Received 13 November 2020

Received in revised form 27 January 2021

Accepted 28 January 2021

\section{Keywords:}

Grape

Honeydew moth

Cryptoblabes gnidiella

Population fluctuation

Sum of effective temperatures

\begin{abstract}
The present study was conducted to determine some biological criteria such as the first appearance of adults, peak date, and a number of generation for controlling honeydew moth in vineyard in Antalya province, Turkey during 2014 and 2015. In this study, the adult population was determined by pheromone traps and larval population was observed by counting the larvae on the grape clusters. It was determined that the pest adults were first seen in mid-April; however, the population was at very low levels until mid-June. It was demonstrated that the adult population of the pest could generate 4 peaks in June, July, August and SeptemberOctober. The study results showed that the pest could be important in coastal vineyards. Besides, it has been showed that the effective temperatures sum based on the degree day model that was proposed in the literature could be employed to determine the honeydew moth adult and larval populations in vineyards.
\end{abstract}

MAKALE BİLGISİ

Alınıs tarihi 13 Kasım 2020

Düzeltilme tarihi 27 Ocak 2021

Kabul tarihi 28 Ocak 2021

Anahtar Kelimeler:

Üzüm

Portakal güvesi

Cryptoblabes gnidiella

Popülasyon değişimi

Etkili sıcaklıklar toplamı

\begin{abstract}
ÖZ
Bu çalışma, bağda Portakal güvesi, Cryptoblabes gnidiella Mill. (Lepidoptera: Pyralidae)'nin mücadelesine ait ilk ergin görülme zamanı, tepe noktaları ve döl sayısı gibi bazı biyolojik kriterlerin belirlenmesi amaciyla Antalya ilinde 2014 ve 2015 yıllarında yürütülmüștür. Çalışmada eşeysel çekici tuzaklar yardımıyla ergin popülasyonu ve salkımlarda yapılan sayımlar ile larva popülasyonu belirlenmiştir. Zararlı erginlerinin doğada ilk kez nisan ayı ortalarında görüldüğü, bununla birlikte haziran ortasına kadar popülasyonun oldukça düşük düzeylerde olduğu belirlenmiştir. Zararlının ergin popülasyonunun haziran, temmuz, ağustos ve eylül-ekim aylarında 4 tepe noktası oluşturduğu belirlenmiştir. Sonuçlar, zararlının özellikle kıyı bölgelerde bağlarda önemli olabileceğini ortaya koymuştur. Ayrıca, bağda Portakal güvesi'nin ergin ve larva popülasyonunun belirlenmesinde, literatürde bildirilen etkili sıcaklıklar toplamı (gün-derece) modelinin başarıyla kullanılabileceği ortaya konulmuştur.
\end{abstract}

\section{Introduction}

Viticulture is important for the Turkish economy. Turkey is the fifth country with 417.041 ha of vineyards, following Spain, China, France, and Italy, and the sixth grape producer with 3.9 million tons, following China, Italy, the US, France, and Spain (FAO 2018). Turkey is the highest dried raisin producer in the world with about 305.000 tons and ranks first in seedless dried raisin exports (TMO 2019).

The most important biotic factor that limits the production and leads to quality problems in grape cultivation is the European grapevine moth, Lobesia botrana Den. et Schiff. (Lepidoptera: Tortricidae). European grapevine moth larvae lead to serious damages, especially by feeding on the grape clusters during the ripening period and by damaging the berries.
The aqueous environment created by the pierced grapes as the larvae feed on them leads to the proliferation of saprophyte fungi. And another pest, the honeydew moth [Cryptoblabes gnidiella Mill. (Lepidoptera: Pyralidae)], becomes a significant threat especially during the harvest season (Bagnoli and Lucchi 2001; TAGEM 2008).

The honeydew moth, which is prevalent in several countries in the subtropical climate zone, is a polyphagous pest (Silva and Mexia 1999; TAGEM 2008). It is active in citrus and pomegranate orchards, vineyards, and cotton fields (Bodenheimer 1951; İren and Ahmad 1973; Mart and Altın 1992; Öztop et al. 2002; TAGEM 2008; Uygun et al. 2010). In recent years, studies conducted in pomegranate orchards in the 
Mediterranean Region (Antalya, Adana, Mersin, and Osmaniye provinces) revealed that the pest led to significant crop losses due to high populations (Öztop et al. 2002; Öztürk and Ulusoy 2009; Uygun et al. 2010). However, there is no previous research on C. gnidiella occurrence in vineyards in Turkey. C. gnidiella damage is quite important in grapevines, especially during the ripening period, as it feeds on berries in grape clusters, leading to rotting.

It is very important to determine base criteria such as the emergence of the pest, population peak, and number of the offspring for successful pest control. Thus, the present study aimed to determine the population growth of $C$. gnidiella in vineyards in Antalya province.

\section{Material and Method}

The populations of Honeydew moth adult and larvae were monitored on approximately 1 hectare of vineyard in Antalya province, Serik district, Kocayatak neighborhood in 2014 and 2015. Most of the vineyard was planted with Trakya İlkeren variety grapevines.

\subsection{Honeydew moth population dynamic}

The population of $C$. gnidiella was monitored by delta type pheromone traps and pheromone $((\mathrm{Z})$-11-hexadecenal $(\mathrm{Z}, 11$ 16: Ald), (E) -11-hexadecenal (E, 11-16: Ald), (Z) -13octadecenal (Z, 13-18: Ald), (E) -13-octadecenal (E, 13-18: Ald)]. Two traps were placed on the vines at $1.5 \mathrm{~m}$ above the ground on the first day of March. The traps were controlled once a week for the moths caught. Pheromone capsules in traps were renewed every 4-5 weeks according to instructions. The sticky sheets were replaced every week.

To determine the larval population of $C$. gnidiella, 50 grape clusters, 2 clusters for each plant were checked with a magnifier when the first adult caught in delta traps. In both years, after the mid of July, the counting's were done on 20 second crop clusters once a week.

\subsection{Generation number of Honeydew moth}

In the study, the offspring were determined based on the growth threshold of $C$. gnidiella and the effective temperature sum (ETS) required for reproduction. The ETS was calculated by subtracting the development threshold from daily mean temperature and expressed in degrees/day, after the appearance of $C$. gnidiella adults. Then, the finding was divided by the ETS value (Öztürk 2018), the period required for the offspring of a single $C$. gnidiella to determine the number of annual offspring of the pest. Furthermore, the finding was compared with the peak values for the adult population caught in delta type traps. During this study, temperatures and relative humidity in the test vineyard were recorded with a data logger (Extech). The findings are presented in Figure 1 for 2014, and in Figure 2 for 2015.

\section{Results}

The number of moths caught in pheromone traps were used to monitor the population dynamic of adult honeydew moths in 2014 and 2015 (Figures 3 and 4). The first adults were identified in the traps on April 14 in 2014 and on April 22 in 2015. However, in both years, the adult population was low until June. After June, the increase in the adult population remained high until November.

In the first year, the initial peak was observed on June $16^{\text {th }}$ (86.5 adults/trap). The number of pests was the highest on August $18^{\text {th }}$ (188.5 adults/trap), after a second peak on July 14 . The final peak was observed on October $7^{\text {th }}$. The larval population was very low, almost zero, during the blooming and veraison periods. The larval population, which started to increase on June 23, reached 1.2 larvae/cluster on August $4^{\text {th }}$. On September 9, the peak was observed in a limited number of small clusters (1.6 larvae/cluster).

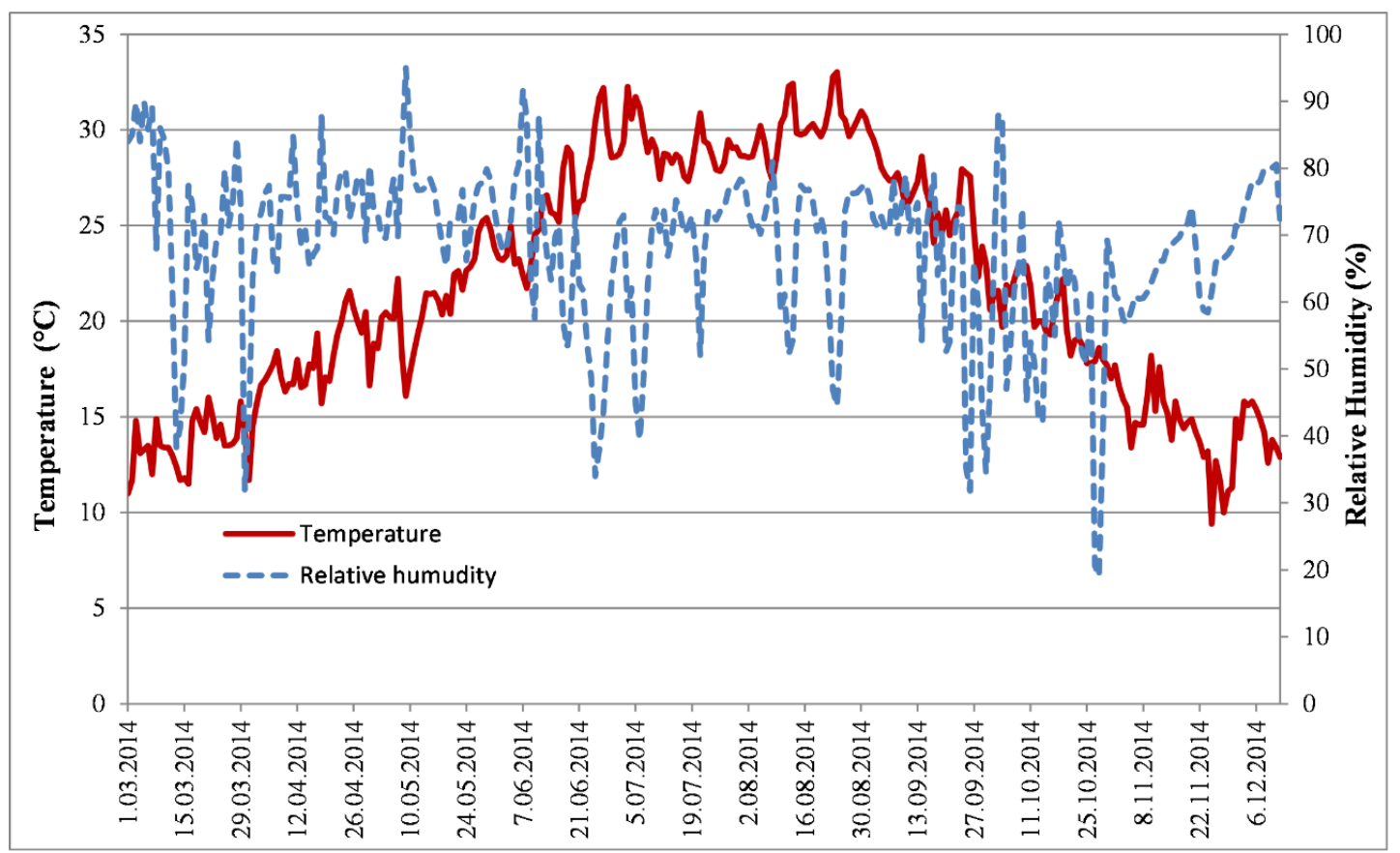

Figure 1. Daily mean temperature $\left({ }^{\circ} \mathrm{C}\right)$ and relative humidity recorded in Antalya in 2014. 


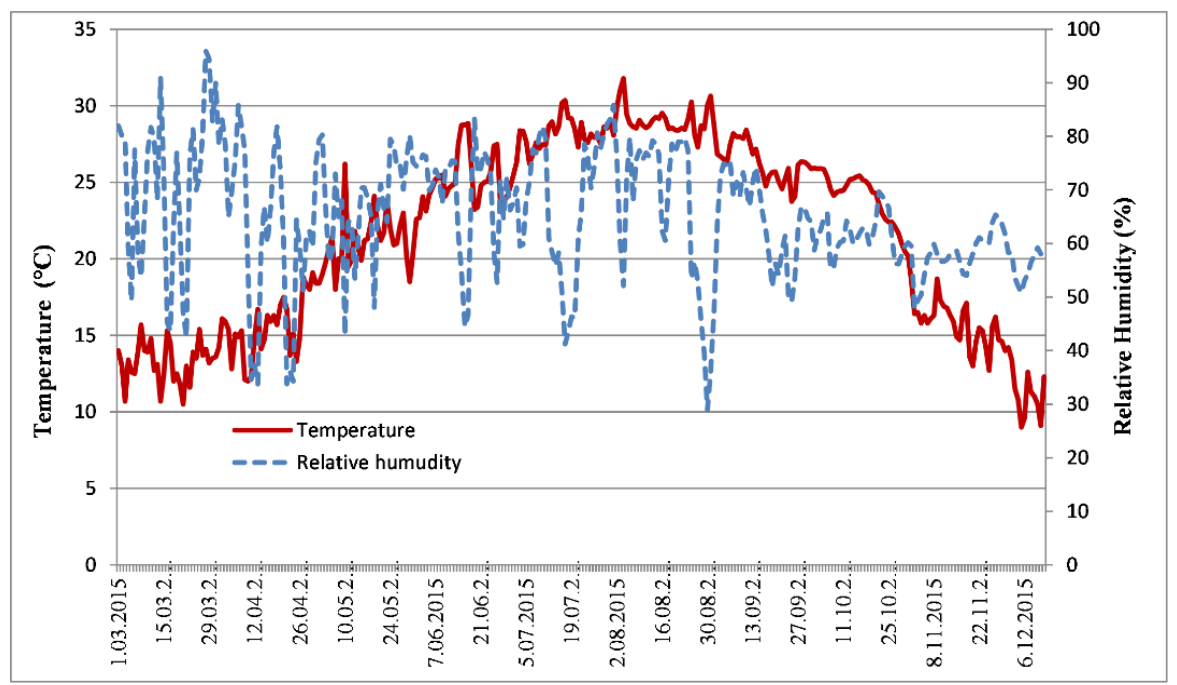

Figure 2. Daily mean temperature $\left({ }^{\circ} \mathrm{C}\right)$ and relative humidity recorded in Antalya in 2015 .

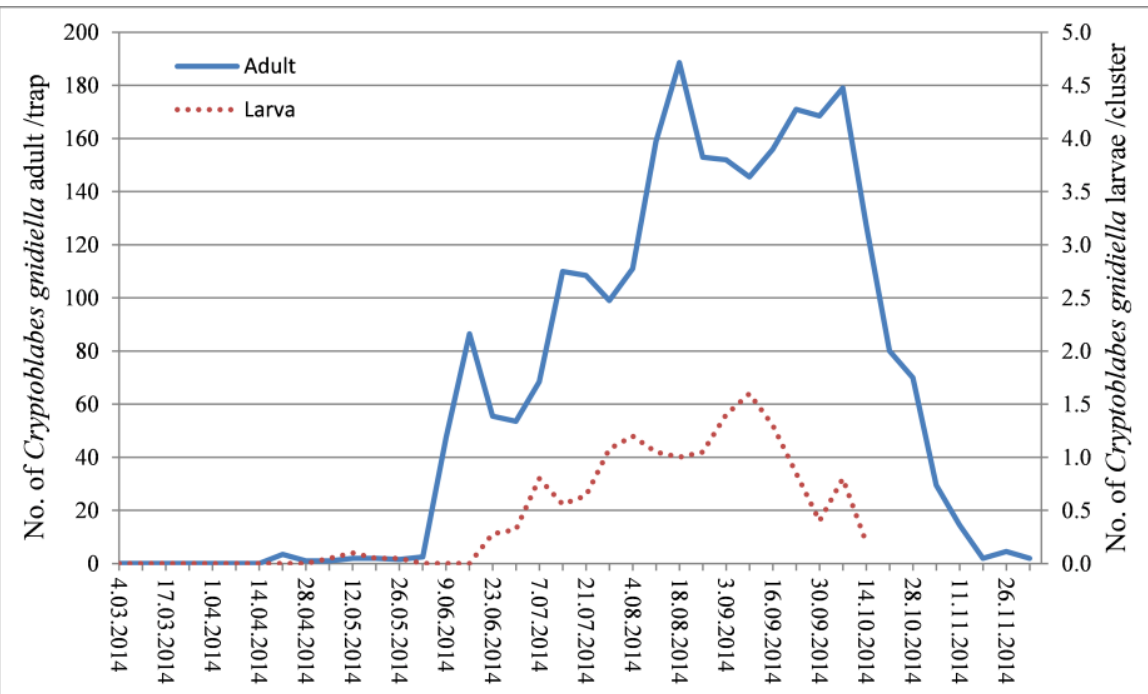

Figure 3. Population dynamic of the Honeydew moth in Antalya in 2014.

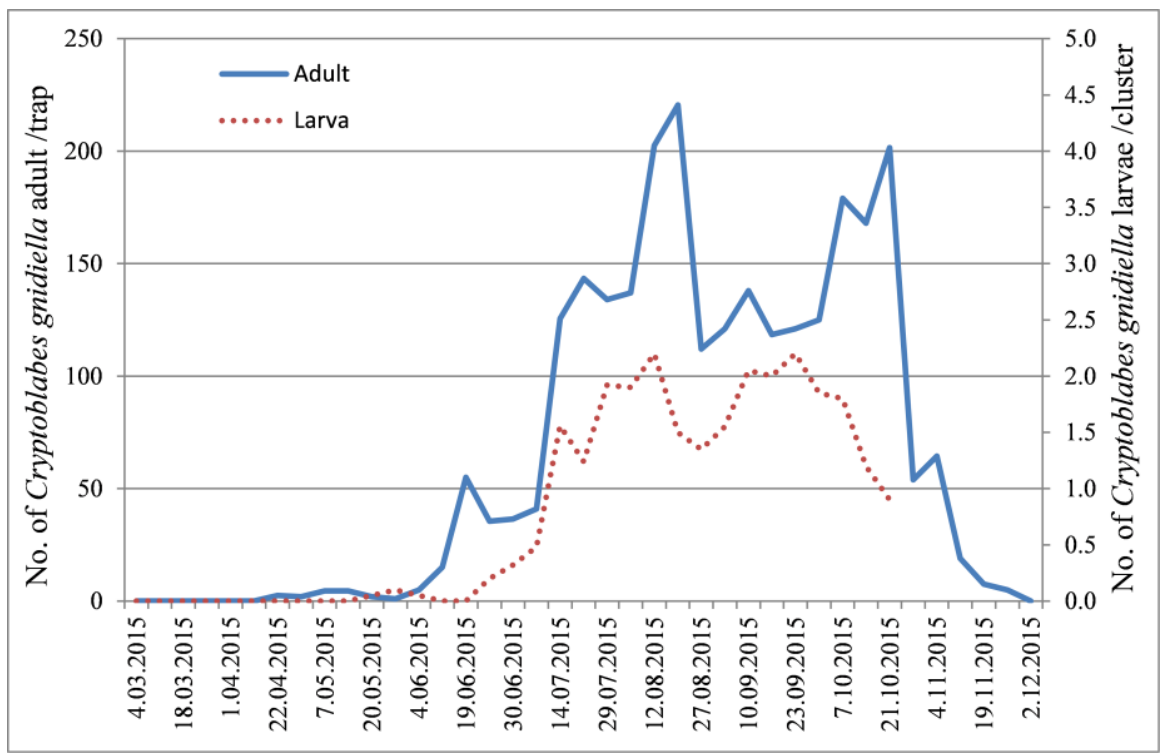

Figure 4. Population dynamic of the Honeydew moth in Antalya in 2015. 
In the second year, the first peak was observed on June 19, and the second peak on July 22 . The adult population was the highest (220.5 adults/trap) on August 20 in the third peak. On the final peak, pest density was determined between 168.0201.5 adults/trap between October 7 and 21. The larval population started to increase on June $25^{\text {th }}$. Between July 1 and 14 , when the grape was in the harvest period, the larval density was 0-48-1.56 larvae/cluster. On August 12 and September 23, it was the highest in a small cluster (2.2 larvae/cluster). As far as we know, no studies reporting the number of $C$. gnidiella larva for grape were previously published.

The annual generation number of C. gnidiella was calculated based on the development threshold in previously reported studies and compared with the number of moths caught in the traps. The minimum growth threshold of $C$. gnidiella was reported as $12^{\circ} \mathrm{C}$ (Ringenberg et al. 2005; Öztürk 2018). Daily mean temperatures were calculated with the data recorded with a data logger. Then, ETS was calculated and compared with the adult emergence ETS reported by Öztürk (2018).

It is reported that the first adult flight from the wintering larval population occurs at 120 day-degree (Öztürk 2018). This value was obtained on April 10 $0^{\text {th }}, 2014$ and April 20 ${ }^{\text {th }}, 2015$ in the current study. The first adult flight, which took place on April 14 in 2014, and on April 22 in 2015, was consistent with previous studies. It was reported that the larvae will hatch after 250 day/degree from the eggs laid by the first adults. ETS reached this value on May 1, 2014, and May 11, 2015. The first larval population was determined on May 5 and May 20, respectively, in current study. It was reported that secondgeneration larvae could be observed after 800 day/degree. In the field where the study was conducted, these values were reached on June 21, 2014, and June 27, 2015. Second-generation larvae were determined about the same dates (June 23, 2014, and June 25, 2015). The ETS values were calculated between April 14December 4, 2014, and April 22-November 25, 2015, when the pest was active. These values were 2695.8 day-degrees for 2014 , and 2666.5 day-degrees for 2015. It was reported that one offspring is completed after 564.6 days in nature (Öztürk 2018). Thus, it was calculated that the pest could yield 4 full offspring (4.77 for 2014 and 4.72 for 2015) under the present study conditions.

Although, the first and second-generation larvae were observed between mid-May and mid-June and mid-June and mid-July, larva of $3^{\text {rd }}$ and $4^{\text {th }}$ generations overlapped. There is no other research reported on larvae to count in grapes in the literature.

\section{Discussion}

The first adults were caught on April 14 in 2014 and April 22 in 2015 in pheromone traps used to monitor the population dynamic of adult honeydew moth. In a study conducted in India, Singh and Singh (1995) reported that C. gnidiella adults emerged first in late March. In another study carried out in Portugal, it was reported that C. gnidiella adults were first caught in traps in late March, and the emergence of wintering offspring adults continued for about 2 months until late May (Silva and Mexia 1999).

In both years, the honeydew moth adult population caught in the traps was low until June and then began to increase. Based on the number of adults caught in the traps, despite overlapping offspring, it was determined that the pest population had 4 peaks in June, July, August, and SeptemberOctober. Similarly, in a study conducted in Italian vineyards, the generations were overlapped, and the adult population had peak 4 times (Bagnoli and Lucchi 2001). In a study conducted in pomegranate orchards in the Eastern Mediterranean Region, it was reported that the pest could have an average of 4-5 generations (Öztürk and Ulusoy 2012; Demirel 2016). Similar findings were also reported for citrus (Öztürk and Ulusoy 2011) and persimmon (Elekcioğlu 2019) in the same region. Carter (1984) reported that $C$. gnidiella could have 3-4 generations in Southern Europe and over 5 in North Africa annually.

The final pest adults were identified in traps on December 4, 2014, and November 25, 2015, and it was revealed that the pest exhibited flight activity in more than 7 months in nature. Similarly, Yehuda et al. (1992) reported that $C$. gnidiella adults last flew in October-November in a study conducted in an avocado orchard in Israel. Singh and Singh (1995) reported that C. gnidiella adults remained active for about 7-7.5 months between late March and November.

The study findings revealed that although the grapevine moth, L. botrana is the main vineyard pest, the honeydew moth, a polyphagous pest, could also reach to significant population sizes. It was also determined that the ETS model could be employed in pest control. Based on the obtained results, it is thought that criteria such as the emergence of first adults, and the peak flight periods can be used in pest control strategies.

Especially when establishing new vineyards in coastal areas, it should be taken into account that the pest uses various plants as host such as orange, citrus, pomegranate, avocado, persimmon trees, as well as corn, cotton, and eggplant.

\section{References}

Bagnoli B, Lucchi A (2001) Bionomics of Cryptoblabes gnidiella (Millière) (Pyralidae Phycitinae) in Tuscan vineyards. IOBC/wprs Bulletin 24: 79-83.

Bodenheimer FS (1951) Citrus Entomology in The Middle East (The Honeydew moth, Cryptoblabes gnidiella Mill.) with Special References to Egypt, Iran, Irak, Palestine, Syria and Turkey. Dr. W. Junk Publishers, The Hague, Netherlands.

Carter DJ (1984) Pest Lepidoptera of Europe with Special Reference to The British Isles. Dr. W. Junk Publishers, Dordrecht, Netherlands.

Demirel N (2016) Seasonal flight patterns of the honeydew moth, Cryptoblabes gnidiella Millière (Lepidoptera: Pyralidae) in pomegranate orchards as observed using pheromone traps. Entomology and Applied Science Letters 3(3): 1-5.

Elekcioğlu N (2019) Adana'da Trabzon hurması bahçelerinde portakal güvesi [Cryptoblabes gnidiella Milliere, 1867 (Lepidoptera: Pyralidae)]'nin popülasyon değişimi, zarar oranı ve mücadelesi. Çukurova Tarım ve Gıda Bilimleri Dergisi 34(2): 149-160.

FAO (2018) FAO Statistics (FAOSTAT). (Web page: http://www.fao.org/faostat/en/\#data/QC). Accessed 4 September, 2020 .

İren Z, Ahmed MK (1973) Insect pest of Turkey found on deciduous fruits. Bitki Koruma Bülteni 1: 35-86.

Mart C, Altın M (1992) Güneydoğu Anadolu Bölgesi nar alanlarında belirlenen böcek ve akar türleri, Türkiye II. Entomoloji Kongresi, Adana, s. 725-735.

Öztop A, Kıvradım M, Tepe S (2002) Antalya ili nar üretim alanlarında bulunan zararlılar ile bunların parazitoitlerinin ve predatörlerinin belirlenmesi ve popülasyon Değişiminin izlenmesi. T.C. Tarım ve 
Köyişleri Bakanlığı, Tarımsal Araștırmalar Genel Müdürlüğü, Ankara. Proje no: Bs-99-06-09-130, Sonuç Raporu, s. 16.

Öztürk N, Ulusoy MR (2009) Pests and natural enemies determined in pomegranate orchards in Turkey. Acta Horticulturae 818: 277-284.

Öztürk N, Ulusoy MR (2011) The adult population dynamics of the Honeydew moth, Cryptoblabes gnidiella Mill., 1867 (Lepidoptera: Pyralidae) in citrus orchards in the Eastern Mediterranean Region. Bitki Koruma Bülteni 51(1): 17-32.

Öztürk N, Ulusoy MR (2012) Determination of adult population dynamics and generation number of Honeydew moth [Cryptoblabes gnidiella Mill., 1867 (Lepidoptera: Pyralidae)] in pomegranate orchards in the Eastern Mediterranean Region. Turkish Journal of Entomology 36(1): 101-112.

Öztürk N (2018) Creating a degree-day model of honeydew moth [Cryptoblabes gnidiella (Mill., 1867) (Lepidoptera: Pyralidae)] in pomegranate orchards. Turkish Journal of Entomology 42: 53-62.

Ringenberg R, Botton M, Garcia MS, Nondillo A (2005) Compared biology in artificial diets and thermal requirements of Cryptoblabes gnidiella. Pesquisa Agropecuaria Brasileria 40: 1059-1065.

Silva EB, Mexia A (1999) The pest complex Cryptoblabes gnidiella (Milliere) and Planococcus citri (Risso) on sweet orange groves
(Citrus sinensis L.) in Portugal: Interspecific association. Boletin de Sanidad Vegetal Plagas 25(1): 89-98.

Singh YP, Singh DK (1995) Bionomics of Cryptoblabes gnidiella Miller a pest of Sorghum. Advances in Agricultural Research in India 3: 119-129.

TAGEM (2008) Zirai Mücadele Teknik Talimatı (Meyve ve Bağ Zararlıları, Cilt: 4), T.C. Tarım ve Köyişleri Bakanlığı, Tarımsal Araştırmalar Genel Müdürlüğü (Tagem), Ankara, pp. 388.

TMO (2019) 2019 y1lı kuru üzüm sektör raporu. Toprak Mahsülleri Ofisi Genel Müdürlüğ̈̈. https://www.tmo.gov.tr/Upload/Document/sektorraporlari/kuruuzu m2019.pdf. Accessed 4 September, 2020.

Uygun N, Ulusoy MR, Karaca İ, Satar S (2010) Meyve ve Bağ Zararlıları. Çukurova Üniversitesi Ziraat Fakültesi Ders Kitapları, Özyurt Matbaacılık, Adana, pp. 347.

Yehuda SB, Wysoki M, Rosen D (1992) Phenology of the Honeydew moth, Cryptoblabes gnidiella (Mill.), on avocado in Israel. Israel Journal of Entomology 25-26: 149-160. 